\title{
Power Generation Expansion Planning Including Large Scale Wind Integration: A Case Study of Oman
}

\author{
Arif S. Malik ${ }^{1}$ and Cornelius Kuba ${ }^{2}$ \\ ${ }^{1}$ College of Engineering, Sultan Qaboos University, 123 Al-Khod, Oman \\ ${ }^{2}$ Mechanical Engieering, Technical University Hamburg, Harburg, Germany \\ Correspondence should be addressed to Arif S. Malik; asmalik@squ.edu.om
}

Received 25 April 2013; Accepted 28 June 2013

Academic Editor: Janaka Ekanayake

Copyright (C) 2013 A. S. Malik and C. Kuba. This is an open access article distributed under the Creative Commons Attribution License, which permits unrestricted use, distribution, and reproduction in any medium, provided the original work is properly cited.

\begin{abstract}
Many options can be effectively used to meet the future power needs of a country in ways which would be more economically viable, environmentally sound, and socially just. A least-cost generation expansion planning study is conducted to find the economic feasibility of large scale integration of wind farms in the main interconnected transmission system of Oman. The generation expansion planning software used is WASP which is restricted in its ability to model intermittent nature of wind. Therefore, a wind turbine is modeled as a thermal plant with high forced outage rate related to its capacity factor. The result of the study has shown that wind turbines are economically viable option in the overall least-cost generation expansion plan for the Main Interconnected System of Oman.
\end{abstract}

\section{Introduction}

In the planning of a power system, it is essential to estimate the operating cost and reliability of the system. To make these estimations, it is important to model the system load and generation units in an appropriate way. Power system planning is made up of the electrical load forecast, generation planning, and electrical network planning $[1,2]$. The electrical load forecast forms the basis of power system planning and provides information on expected consumption increase, load curve profiles, and load distribution. The result of generation planning and electrical network can also conversely exert an influence on electrical load curve or distribution via marginal cost effort. In the planning process, major decisions in expansion planning of the generation system must consider alternative generating unit sizes, types of capacity, timing of addition, and locations. The main sources of uncertainty in strategic planning are forecasts of electricity demand, fuel prices and availability, availability and performance of new technology, governmental policies toward privatization and regulations, and public attitudes [3].

This paper reports a study that was aimed to find a leastcost generation expansion plan for the Main Interconnected
System (MIS) of Oman considering the large scale integration of wind energy. The importance of the study is to show how wind turbines can be modeled in generation expansion planning software models that are based on load duration curve technique and that wind energy system can form part of the least-cost plan in Oman while keeping the same planning standard of minimum reserve margin and cost of unserved energy.

The study is limited by its scope as no detailed investigation of wind energy sites and their true potential is estimated. However, ample literature on wind energy potential and its application in Oman is available which suggests that there is a significant potential available in the southern part and the coastal area of the country [4-10]. The study also does not consider the cost related to wind power evacuation from the south to the north of the country where the major load exists. The load and generation data used is taken from Oman Power and Water Procurement (OPWP) company's report [11] and private communications to OPWP personnel. The candidate plants used for expanding the generation system are taken those which are presently in the Omani power system with the exception of wind plants. The generation expansion planning is done using Wien Automatic System 


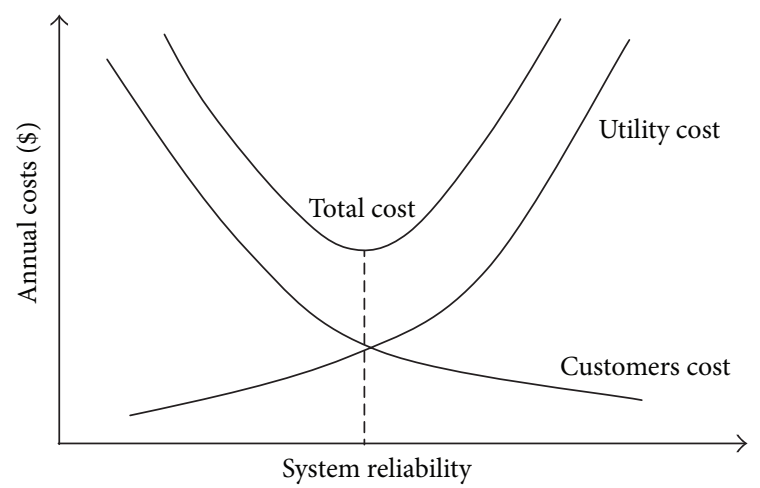

FIgURE 1: Relationship between consumers, utility, and total annual cost with respect to reliability.

Planning (WASP) software [12]. The software has its own modeling limitations; for example, the load model is based on the load duration curve (LDC). LDC model provides information about the percentage of time the load equals or exceeds a certain MW value and gives the same energy information as the actual chronological load curve; however, the chronology of the events is lost which poses modeling limitations to nondispatchable technologies such as wind.

This paper is arranged in six sections. Section 1 is an introduction. Section 2 is a theoretical review of power planning concepts. Section 3 is a review of wind energy potential in Oman. Section 4 discusses how wind plants can be modeled in WASP. Section 5 provides generation and load data of MIS system. Section 6 presents the results of the generation expansion planning. And the last section concludes the paper.

\section{Electric Power System Planning}

2.1. Objective of Power Planning Study. The objective of electric planning study is to meet the load forecast with high reliability at a minimum cost. There are three keywords in the previous statement, that is, load forecast, reliability, and cost. A brief discussion on these three keywords is followed. The cost is minimized depending on the financial resources, technical, environmental, and political considerations. Four questions must be answered when the study of capacity planning is done [1].

(1) What type of capacities will be added to the system?

(2) How much capacities will be added?

(3) When these capacities will be added?

(4) Where these capacities will be located?

The first three questions can be answered by using any generation expansion planning software. However, for the question where to locate the new facilities a detailed feasibility study has to be carried out considering the load center, availability of fuel, water, manpower, transmission corridors, and so forth. The objective function of the least-cost-planning software is normally the following.
Minimize for all $j$,

$$
B_{j}=\sum_{i=1}^{n}\left(\overline{\mathrm{CC}}_{i}-\overline{\mathrm{SV}}_{i}+\overline{\mathrm{FC}}_{i}+\overline{\mathrm{O}_{i} \& \mathrm{M}_{i}}+\overline{\mathrm{UE}}_{i}\right)
$$

where
CC is the capital cost;
$\mathrm{SV}$ is the salvage value;
FC is the fuel cost;
$\mathrm{O} \& \mathrm{M}$ is the operating and maintenance cost;

UE is the energy not served cost;

$n$ is number of years in study period;

And over bar $\left(^{-}\right)$on the above costs represents present worth of all the costs.

The capital costs of only candidate generating plants considered for expansion are added in the objective function. The capital costs of existing plants and those in the construction phase (committed plants) in the system are considered sunk and are thus not considered in the objective function.

2.2. Generation Planning Study Period. The study period normally spans from twenty to twenty-five years. The study period consists of three subperiods: preplanning period, planning period, and postplanning period [13]. Preplanning period is the first 3-4 years in which the planning was done earlier. This is included in the study period to see the energy production cost and reliability of the system. The planning period is between 4 and 10 years in which the decision has to be taken now about the plants that have to be added in the future to meet the forecast. The post-planning period is added in the study period to avoid the end effects by making the calculations continue for another 10 years or more so that a proper tradeoff between construction costs and operating costs is found. Therefore, the long-term forecasts of 20-25 years of electricity consumption and demand are used in the planning of investment in generating capacity and the development of fuel supplies.

2.3. Reliability. Reliability is the ability of a system or component to perform its required functions under stated conditions for a specified period of time $[14,15]$. In (1) the reliability is also embedded in terms of cost of energy not served. This cost is basically customers' electricity outages cost and is the penalty for unreliability. If more capacity is added in the system, the capital cost would be high but because of more capacity in the system the total unserved energy cost would be low as the system would be more reliable. On the other hand, if the capacity added is less than the actual required, then there would be more customer outages and hence higher unserved energy cost. The basic concept of reliability-cost/reliability-worth evaluation is relatively simple and can be presented by the cost/reliability curves, as shown in Figure $1[14,15]$. These curves show that the investment cost generally increases with higher reliability, that is, capital investment is augmented in order to improve 


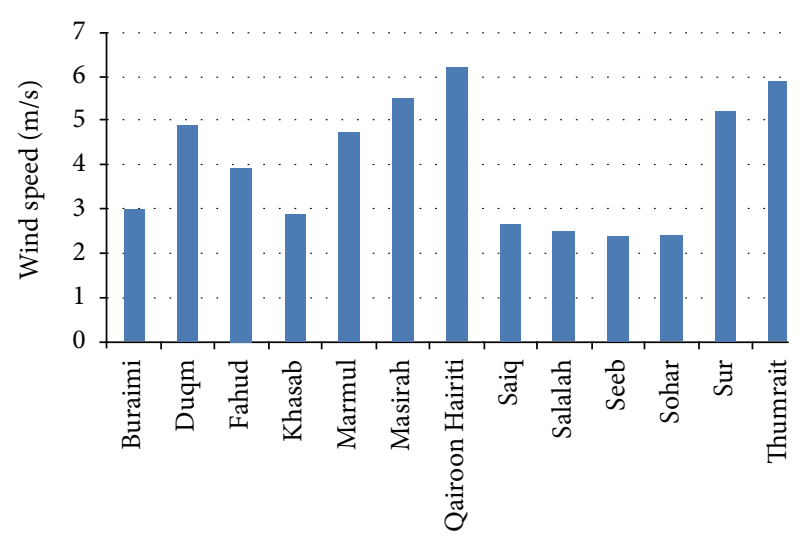

FIGURE 2: Annual average wind speeds of some sites in Oman at $10 \mathrm{~m}$ height.

the reliability. On the other hand, the customers' outages cost decreases as the reliability increases. Furthermore, the total cost of the two curves is the sum of the utility cost and the customers cost, and the minimum exhibits the optimal cost.

\section{Wind Energy Potential in Oman}

The wind speed in Oman is relatively high compared with other gulf countries. Oman's southern region appears to have the highest wind potential. Figure 2 shows the average wind speed in some of the cities in Oman. The highest wind potential is in Quiroon Hariti and Thumrait and both are in the South of Oman. A brief literature review on wind energy potential in Oman is presented in the following paragraphs.

In [6], it is concluded that with the existing gas price of 1.5 US\$/MMBtu wind energy is not economical for grid application. The wind energy at Quiroon Hariti, (see Figure 2) the highest wind potential in Oman, becomes marginally economical at a gas price of $6 \$ / \mathrm{MMBtu}$. At the opportunity cost of natural gas price of approximately $3 \$ / M M B t u$ and adding a depletion premium of $3 \%$ per annum, the cost of wind energy become comparable to open cycle gas-turbine (GT) power plants. The combined cycle (CCGT) power plants remain cheaper, however. The comparison is made by assuming the economic life of assets (GT, CCGT, and $20 \mathrm{MW}$ wind farm) to be 25 years and the real discount rate at $7.55 \%$.

In [7], the electricity generation from wind energy for Duqm, a coastal region, was investigated based on the monthly mean wind speed observations. A technoeconomic evaluation was also presented using V90-1.8 turbine. It was concluded that the power generation cost is higher than the current existing system, due to the highly subsidized price of natural gas. In [8], a single $50 \mathrm{~kW}$ wind turbine of TekVal was used to demonstrate the economical utilization of the wind energy at the site. It was concluded that the operating cost of the diesel generation was 1.7-1.8 times the specific cost of wind turbine. It was also concluded that the simple payback period of the turbine was about five years.

In [9], five-year hourly wind data is analyzed from twenty-nine weather stations to identify the potential location for wind energy applications in Oman. Different criteria
TABLE 1: Technical data of wind turbine.

\begin{tabular}{lccccccc}
\hline $\begin{array}{l}\text { Wind } \\
\text { mach. }\end{array}$ & $\begin{array}{c}\text { Rated } \\
\text { power } \\
(\mathrm{kW})\end{array}$ & $\begin{array}{c}\text { Cut-in } \\
(\mathrm{m} / \mathrm{s})\end{array}$ & $\begin{array}{c}\text { Cut-out } \\
(\mathrm{m} / \mathrm{s})\end{array}$ & $\begin{array}{c}\text { Rated } \\
\text { speed } \\
(\mathrm{m} / \mathrm{s})\end{array}$ & $\begin{array}{c}\text { Hub } \\
\text { height } \\
(\mathrm{m})\end{array}$ & $\begin{array}{c}\text { Rotor } \\
\text { Dia } \\
(\mathrm{m})\end{array}$ & $\begin{array}{c}\text { Expected } \\
\text { life } \\
(\mathrm{yrs})\end{array}$ \\
\hline V80 & 2000 & 4 & 25 & 16 & 67 & 80 & 20 \\
\hline
\end{tabular}

including theoretical wind power output, vertical profile, turbulence, and peak demand fitness were considered to identify the potential locations. Air density and roughness length, which play an important role in the calculation of the wind power density potential, are derived for each station site. Due to the seasonal power demand, a seasonal approach is also introduced to identify the wind potential on different seasons. Finally, a scoring approach was introduced in order to classify the potential sites based on the different factors mentioned previously. It is concluded that Qairoon Hairiti, Thumrait, Masirah, and Ras Alhad have high wind power potential and that Quiroon Hariti is the most suitable site for wind power generation.

In [10], the article assessed wind power cost per $\mathrm{kWh}$ of energy produced using four types of wind machines at 27 locations within Oman. These sites cover all regions in Oman. Hourly values of wind speed recorded between 2000 and 2009, in most cases, were used for all 27 locations. Wind duration curves were developed and utilized to calculate the cost per kWh of energy generated from four chosen wind machines. It was found that the cost of energy is low in the south and middle regions of Oman compared with that in the north region. According to the study, the most promising sites for the economic harnessing of wind power are Thumrait, Qairoon Hairiti, Masirah, and Sur, with an energy cost of less than 0.117 US $\$ / \mathrm{kWh}$ when $2000 \mathrm{~kW}, 1500 \mathrm{~kW}, 850 \mathrm{~kW}$, or $250 \mathrm{~kW}$ wind turbines are used.

\section{Wind Plant Modeling in WASP}

As mentioned in the introduction that the load model in WASP software is based on the load duration curve (LDC) technique. LDC model provides information about the percentage of time the load equals or exceeds a certain MW value and gives the same energy information as the actual chronological load curve. However, the chronology of the events is lost in LDC models which pose modeling limitations for nondispatchable technologies such as wind which are inherently chronological devices that operate according to the availability of wind. There are several ways to model wind turbine/plant in WASP and all have some kind of approximation. Here are some of the ways to handle it.

(1) Wind turbine/plant can be modeled as a thermal plant with zero fuel cost and increased forced outage rate to reflect the variability of wind and reduced capacity credit of wind turbine. With zero fuel cost, the economic loading order of wind turbine is first in the merit and can be considered as a base load plant.

(2) Wind turbine is modeled as negative load. The expected energy produced by a wind turbine can first 
TABLE 2: Data of wind turbine for WASP.

\begin{tabular}{lccccccc}
\hline Type & $\begin{array}{c}\text { Max. capacity } \\
(\mathrm{MW})\end{array}$ & $\begin{array}{c}\text { Forced } \\
\text { outage rate }\end{array}$ & $\begin{array}{c}\text { Sch. maintenance } \\
\text { days }\end{array}$ & $\begin{array}{c}\text { Fixed O\&M cost } \\
\$ / \mathrm{kW} \text {-month }\end{array}$ & $\begin{array}{c}\text { Capital } \\
\text { cost \$/kW }\end{array}$ & $\begin{array}{c}\text { Life (yrs) } \\
\text { Construction } \\
\text { time }(\mathrm{yr})\end{array}$ \\
\hline Wind & 20 & $75.4 \%$ & 10 & 1.46 & 1500 & 20 & 1 \\
\hline
\end{tabular}

TABLE 3: Technical and cost data of thermal plants in the year 2012.

\begin{tabular}{|c|c|c|c|c|c|c|c|c|c|c|c|}
\hline \multirow{3}{*}{ No. } & \multirow{3}{*}{$\begin{array}{l}\text { Plant } \\
\text { name }\end{array}$} & \multirow{3}{*}{$\begin{array}{l}\text { No. of } \\
\text { sets }\end{array}$} & \multirow{3}{*}{$\begin{array}{l}\text { Min. load } \\
\text { MW }\end{array}$} & \multirow{3}{*}{$\begin{array}{c}\text { Capacity } \\
\text { MW }\end{array}$} & \multicolumn{2}{|c|}{$\begin{array}{l}\text { Heat rates } \\
\mathrm{kcal} / \mathrm{kWh}\end{array}$} & \multirow{3}{*}{$\begin{array}{l}\text { Fast spin } \\
\text { Res \% }\end{array}$} & \multirow{3}{*}{$\begin{array}{c}\text { FOR } \\
\%\end{array}$} & \multirow{3}{*}{$\begin{array}{c}\text { Sched. } \\
\text { Maintenance } \\
\text { days }\end{array}$} & \multirow{3}{*}{$\begin{array}{l}\text { O\&M (FIX) } \\
\$ / \text { kW-month }\end{array}$} & \multirow{3}{*}{$\begin{array}{l}\text { O\&M } \\
\text { (VAR) } \\
\text { \$/MWh }\end{array}$} \\
\hline & & & & & Base & Incr. & & & & & \\
\hline & & & & & load & load & & & & & \\
\hline 1 & GBG5 & 8 & 6 & 16 & 4728 & 2434 & 9 & 10 & 27 & 3.78 & 0.18 \\
\hline 2 & GBG6 & 2 & 11 & 26 & 4176 & 2116 & 9 & 10 & 31 & 5.21 & 0.18 \\
\hline 3 & GBG9 & 2 & 91 & 91 & 2705 & 2705 & 0 & 5 & 31 & 7.17 & 0.18 \\
\hline 4 & GBS1 & 1 & 37 & 37 & 1811 & 1811 & 0 & 50 & 34 & 5.68 & 0.37 \\
\hline 5 & GBS2 & 2 & 30 & 30 & 1058 & 1058 & 0 & 20 & 25 & 8.91 & 0.37 \\
\hline 6 & RUSL & 8 & 45 & 86 & 3713 & 2224 & 9 & 5 & 27 & 3.57 & 2.26 \\
\hline 7 & WJZ1 & 8 & 12 & 27 & 4204 & 2205 & 9 & 5 & 31 & 6.50 & 0.18 \\
\hline 8 & WJZ2 & 5 & 6 & 17 & 4701 & 2430 & 9 & 5 & 30 & 6.50 & 0.18 \\
\hline 9 & MNH1 & 3 & 12 & 29 & 4301 & 2253 & 9 & 2 & 20 & 6.52 & 3.24 \\
\hline 10 & MNH2 & 2 & 42 & 94 & 3455 & 2215 & 9 & 2 & 30 & 6.52 & 2.13 \\
\hline 11 & ALK & 3 & 44 & 99 & 3515 & 2326 & 9 & 2 & 37 & 6.57 & 3.32 \\
\hline 12 & BRK1 & 1 & 108 & 435 & 3257 & 1756 & 9 & 3 & 20 & 9.08 & 1.44 \\
\hline 13 & BRK2 & 1 & 126 & 710 & 2114 & 1742 & 9 & 4 & 20 & 7.07 & 1.16 \\
\hline 14 & BRK3 & 2 & 40 & 247 & 1797 & 1455 & 9 & 3 & 20 & 20.05 & 1.04 \\
\hline 15 & SHR1 & 1 & 121 & 590 & 3467 & 1821 & 9 & 3 & 20 & 5.84 & 1.28 \\
\hline 16 & SHR2 & 2 & 40 & 247 & 1797 & 1455 & 9 & 3 & 20 & 20.05 & 1.04 \\
\hline 17 & SURa & 0 & 400 & 799 & 1771 & 1316 & 9 & 3 & 20 & 13.01 & 0.66 \\
\hline 18 & SURb & 0 & 201 & 401 & 1711 & 1316 & 9 & 3.5 & 20 & 13.01 & 0.66 \\
\hline
\end{tabular}

be subtracted from the original chronological load curve and then the load duration curve is made. The optimization is then done without considering wind turbines and the cost of wind turbine can then be added later in the optimal case.

(3) Wind turbine can be derated according to the capacity credit and modeled as a thermal plant with zero fuel cost and a normal forced outage rate of say about $4 \%$ can be assigned.

(4) Wind turbine is modeled as a hydroplant with a base load capacity and inflow energy as a constraint. The inflow energy reflects the energy the wind turbine can produce in a given load duration curve time span.

In the present study, a wind turbine is modeled as a thermal plant with high forced outage rate to investigate the economic feasibility of wind plants. This technique is closer to reality as the higher forced outage rate force the WASP model to select more plants to meet the reliability requirement. In real systems also because of poor capacity credit attributed to wind energy a lot of backup supply has to be provided. The candidate plant of $2 \mathrm{MW}$ taken from [10] is used to demonstrate the economic feasibility at one of the best sites of Thumrait. Table 1 gives the technical data of wind turbine.
The annual energy produced by this wind turbine at the site is $4318 \mathrm{MWh}$ from which its forced outage rate is calculated from its capacity factor using the following two formulas:

$$
\text { Capacity Factor }=\frac{\text { Annual Energy Produced }(\mathrm{MWh})}{\text { Rated Capacity }(\mathrm{MW}) \times 8760 \mathrm{hrs}} .
$$

Forced Outage Rate $=1-$ Capacity Factor.

It is assumed that 10 wind turbines of $2 \mathrm{MW}$ size form a wind park of $20 \mathrm{MW}$. This $20 \mathrm{MW}$ is used as a candidate plant instead of $2 \mathrm{MW}$ wind turbine. The other needed data for WASP is shown in Table 2.

\section{MIS Generation and Load Data}

5.1. Generation Data. The generation expansion planning is carried out for the MIS from 2012 to 2034. The main Interconnected System consists of ten existing plants Ghubrah, Rusail, Wadi Al-Jizzi, Manah, Barka-I, Barka-II, Barka-III, Sohar-I, Sohar-II, and Alkamil. All the plants are either combustion turbines or combined cycle plants. The fixed or existing system consists of about $4770 \mathrm{MW}$ capacity [11]. The 
TABLE 4: Technical and cost data of candidate plants.

\begin{tabular}{|c|c|c|c|c|c|c|c|c|c|c|c|c|c|}
\hline \multirow{3}{*}{ No. } & \multirow{3}{*}{$\begin{array}{l}\text { Plant } \\
\text { name }\end{array}$} & \multirow{3}{*}{$\begin{array}{l}\text { Min. load } \\
\text { MW }\end{array}$} & \multirow{3}{*}{$\begin{array}{c}\text { Capacity } \\
\text { MW }\end{array}$} & \multicolumn{2}{|c|}{ Heat rates } & \multirow{3}{*}{$\begin{array}{l}\text { Fast spin } \\
\text { Res \% }\end{array}$} & \multirow{3}{*}{$\begin{array}{c}\text { FOR } \\
\%\end{array}$} & \multirow{3}{*}{$\begin{array}{c}\text { Sched. } \\
\text { maintenance } \\
\text { days }\end{array}$} & \multirow{3}{*}{$\begin{array}{l}\text { O\&M (FIX) } \\
\$ / \mathrm{kW} \text {-month }\end{array}$} & \multirow{3}{*}{$\begin{array}{l}\text { O\&M } \\
\text { (VAR) } \\
\$ / \mathrm{MWh}\end{array}$} & \multirow{3}{*}{$\begin{array}{l}\text { Capital } \\
\text { cost } \\
\$ / \mathrm{kWh}\end{array}$} & \multirow{3}{*}{$\begin{array}{l}\text { Plant } \\
\text { life } \\
\text { (yrs) }\end{array}$} & \multirow{3}{*}{$\begin{array}{c}\text { Construction } \\
\text { time }\end{array}$} \\
\hline & & & & Base & Incr & & & & & & & & \\
\hline & & & & load & load & & & & & & & & \\
\hline 1 & GBG9 & 91 & 91 & 2705 & 2705 & 0 & 5 & 31 & 7.17 & 0.18 & 795 & 25 & 3 \\
\hline 2 & BRK1 & 108 & 435 & 3257 & 1756 & 9 & 3 & 20 & 9.08 & 1.44 & 977 & 25 & 3 \\
\hline 3 & FCOL & 83 & 250 & 2800 & 2300 & 10 & 8 & 35 & 2.92 & 5.00 & 2000 & 25 & 5 \\
\hline
\end{tabular}

TABLE 5: Results of base case: costs, reliability, type, and number of units selected.

\begin{tabular}{|c|c|c|c|c|c|c|c|c|c|c|}
\hline \multirow{2}{*}{ Year } & \multicolumn{6}{|c|}{ Present worth cost of the year in thousands dollars } & \multirow{2}{*}{ LOLP \% } & \multirow{2}{*}{ GBG9 } & \multirow{2}{*}{ BRK1 } & \multirow{2}{*}{ FCOL } \\
\hline & Const. cost & Salvage value & $\begin{array}{c}\text { Operating } \\
\text { cost }\end{array}$ & $\begin{array}{l}\text { Energy not } \\
\text { served cost }\end{array}$ & Total & $\begin{array}{c}\text { Obj. Fn } \\
\text { (Cumulative) }\end{array}$ & & & & \\
\hline 2034 & 81646 & 73253 & 631261 & 0 & 639654 & 21847338 & 0.028 & 74 & 15 & 0 \\
\hline 2033 & 104834 & 84241 & 651639 & 0 & 672232 & 21207684 & 0.024 & 69 & 15 & 0 \\
\hline 2032 & 109827 & 78893 & 670504 & 0 & 701438 & 20535452 & 0.031 & 63 & 15 & 0 \\
\hline 2031 & 117515 & 75307 & 689700 & 0 & 731908 & 19834014 & 0.028 & 63 & 14 & 0 \\
\hline 2030 & 826712 & 471547 & 709039 & 0 & 1064204 & 19102106 & 0.027 & 63 & 13 & 0 \\
\hline 2029 & 337793 & 171065 & 699590 & 126 & 866444 & 18037902 & 0.047 & 42 & 10 & 0 \\
\hline 2028 & 143960 & 64548 & 734243 & 123 & 813778 & 17171458 & 0.046 & 39 & 8 & 0 \\
\hline 2027 & 104885 & 41510 & 752857 & 235 & 816467 & 16357680 & 0.055 & 39 & 7 & 0 \\
\hline 2026 & 112227 & 39068 & 777024 & 262 & 850445 & 15541213 & 0.055 & 35 & 7 & 0 \\
\hline 2025 & 412757 & 125894 & 802078 & 327 & 1089268 & 14690768 & 0.058 & 31 & 7 & 0 \\
\hline 2024 & 188703 & 50204 & 812510 & 372 & 951381 & 13601500 & 0.057 & 29 & 5 & 0 \\
\hline 2023 & 708848 & 163664 & 830018 & 796 & 1375999 & 12650119 & 0.085 & 29 & 4 & 0 \\
\hline 2022 & 252822 & 50358 & 823948 & 867 & 1027279 & 11274120 & 0.086 & 26 & 1 & 0 \\
\hline 2021 & 157404 & 26859 & 846190 & 1015 & 977749 & 10246841 & 0.092 & 25 & 0 & 0 \\
\hline 2020 & 252633 & 36626 & 867924 & 1639 & 1085570 & 9269092 & 0.124 & 21 & 0 & 0 \\
\hline 2019 & 450528 & 54940 & 893340 & 1709 & 1290638 & 8183523 & 0.121 & 15 & 0 & 0 \\
\hline 2018 & 241033 & 24418 & 910721 & 2313 & 1129649 & 6892885 & 0.144 & 5 & 0 & 0 \\
\hline 2017 & 0 & 0 & 933210 & 535 & 933745 & 5763236 & 0.047 & 0 & 0 & 0 \\
\hline 2016 & 0 & 0 & 961424 & 0 & 961424 & 4829492 & 0.006 & 0 & 0 & 0 \\
\hline 2015 & 0 & 0 & 996447 & 0 & 996447 & 3868068 & 0 & 0 & 0 & 0 \\
\hline 2014 & 0 & 0 & 997687 & 0 & 997687 & 2871621 & 0.001 & 0 & 0 & 0 \\
\hline 2013 & 0 & 0 & 965412 & 965 & 966377 & 1873934 & 0.071 & 0 & 0 & 0 \\
\hline 2012 & 0 & 0 & 906425 & 1132 & 907557 & 907557 & 0.076 & 0 & 0 & 0 \\
\hline
\end{tabular}

committed plants and the retirements are also taken into account. Table 3 provides technical and economic data for the fixed system and committed plants. All power plants are powered by natural gas, which comes from domestic production with a fuel cost of $1189 \$ / 10^{6} \mathrm{kcal}$ equivalent to $\$ 3 / \mathrm{MMBtu}$. The last two plants with zero number of sets show the committed plants. Table 4 provides the technical and economic data of units taken as candidate plants for expansion.

5.2. Load Data. As mentioned earlier, the load model in WASP is of load duration curve. The annual chronological hourly load curve of year 2009 is used to make load duration curves (LDC) for winter and summer seasons. Figure 3 shows a summer load duration curve with inverted axes. The figure shows that load of $1100 \mathrm{MW}$ or more needs to be served all times and more than $3000 \mathrm{MW}$ needs to be served for around $8 \%$ of time. These summer and winter LDCs are then normalized and the shapes of LDCs are assumed the same for the whole study period. The peak load for the 2012 is $4189 \mathrm{MW}$ and for year 2034 (the end of study period) is $12,617 \mathrm{MW}$ with an average load growth of about $5 \%$. Figure 4 shows the peak load from 2012 till 2034.

5.3. Economic Data. The discount rate used for the study is $7.5 \%$ and the cost of unserved energy as $1.6 \$ / \mathrm{kWh}$. The discount rate of $7.5 \%$ has been used in earlier official studies; see for example [6]. The cost of unserved energy was worked 
TABLE 6: Results of base case: costs, reliability, type, and number of units selected.

\begin{tabular}{|c|c|c|c|c|c|c|c|c|c|c|}
\hline \multirow{2}{*}{ Year } & \multicolumn{6}{|c|}{ Present worth cost of the year in thousands dollars } & \multirow{2}{*}{ LOLP \% } & \multirow{2}{*}{ GBG9 } & \multirow{2}{*}{ BRK1 } & \multirow{2}{*}{ Wind } \\
\hline & Const. cost & Salvage value & $\begin{array}{c}\text { Operating } \\
\text { cost }\end{array}$ & $\begin{array}{l}\text { Energy not } \\
\text { served cost }\end{array}$ & Total & $\begin{array}{c}\text { Obj. Fn } \\
\text { (cumulative) }\end{array}$ & & & & \\
\hline 2034 & 112256 & 100716 & 604143 & 1883 & 617566 & 21721956 & 0.284 & 63 & 15 & 51 \\
\hline 2033 & 113361 & 90334 & 619355 & 2361 & 644744 & 21104390 & 0.328 & 62 & 14 & 51 \\
\hline 2032 & 125332 & 89652 & 640912 & 1968 & 678560 & 20459646 & 0.276 & 58 & 14 & 45 \\
\hline 2031 & 125810 & 80370 & 658514 & 2096 & 706050 & 19781086 & 0.282 & 58 & 13 & 43 \\
\hline 2030 & 846035 & 480353 & 675986 & 2353 & 1044020 & 19075036 & 0.299 & 58 & 12 & 42 \\
\hline 2029 & 333885 & 168326 & 669359 & 2367 & 837284 & 18031016 & 0.26 & 39 & 9 & 35 \\
\hline 2028 & 143960 & 64549 & 706327 & 1849 & 787588 & 17193732 & 0.207 & 37 & 7 & 33 \\
\hline 2027 & 154038 & 60963 & 723468 & 2484 & 819027 & 16406144 & 0.25 & 37 & 6 & 33 \\
\hline 2026 & 190940 & 58496 & 740582 & 3493 & 876519 & 15587117 & 0.317 & 37 & 5 & 33 \\
\hline 2025 & 411400 & 124215 & 775462 & 1787 & 1064434 & 14710598 & 0.177 & 36 & 5 & 19 \\
\hline 2024 & 128488 & 34184 & 787557 & 2170 & 884031 & 13646164 & 0.187 & 29 & 4 & 17 \\
\hline 2023 & 739292 & 158541 & 810692 & 2817 & 1394260 & 12762133 & 0.219 & 25 & 4 & 17 \\
\hline 2022 & 216046 & 43033 & 829179 & 1085 & 1003277 & 11367873 & 0.098 & 16 & 3 & 1 \\
\hline 2021 & 231169 & 39447 & 853933 & 792 & 1046448 & 10364596 & 0.076 & 16 & 2 & 1 \\
\hline 2020 & 306917 & 43548 & 869463 & 1793 & 1134626 & 9318148 & 0.131 & 16 & 1 & 1 \\
\hline 2019 & 450528 & 54940 & 893340 & 1709 & 1290638 & 8183523 & 0.121 & 15 & 0 & 0 \\
\hline 2018 & 241033 & 24418 & 910721 & 2313 & 1129649 & 6892885 & 0.144 & 5 & 0 & 0 \\
\hline 2017 & 0 & 0 & 933210 & 535 & 933745 & 5763236 & 0.047 & 0 & 0 & 0 \\
\hline
\end{tabular}

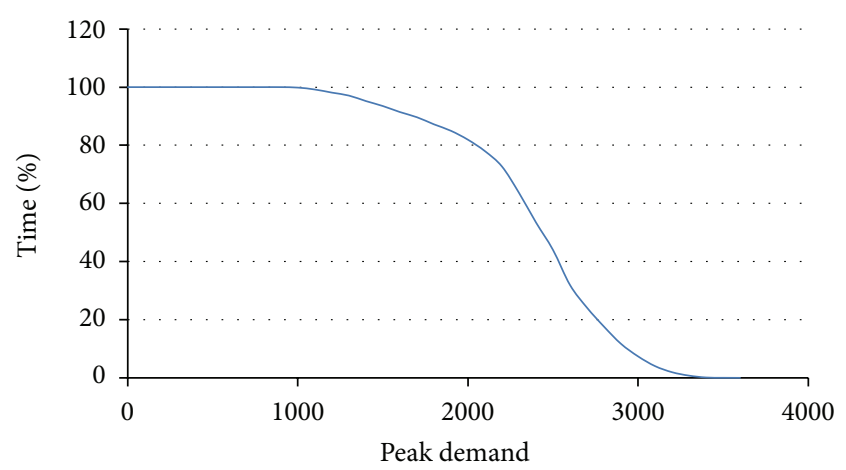

FIgURE 3: Load duration curve with inverted axis.

out in [15] and is consistent with the optimal reserve margins found using the cost of unserved energy and the average reserve margins existing in Oman.

\section{Results and Discussions}

Table 5 provides the results of a base case without the option of wind turbines. It may be noted that FCOL is not selected at all. The results show that by the year 2034 seventy-four units of GBG9 and fifteen units of BRK1 are selected with total capacity addition of $13,259 \mathrm{MW}$ in the system. The existing generating units of Table 3 will all retire during the study period. The loss-of-load probability (LOLP) of $0.028 \%$ in year 2034 corresponds to loss-of-load expectation of about 0.1 day per year or 1 day in 10 years. The total objective function cost is about 21.85 billion dollars.

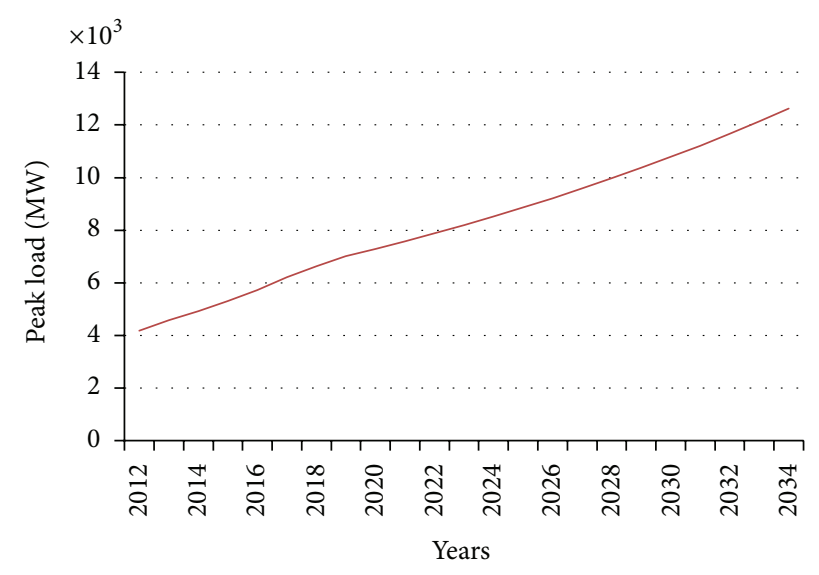

FIgURE 4: Annual peak demand from 2012 to 2034.

The result of taking $20 \mathrm{MW}$ wind park as a candidate unit is shown in Table 6. It may be noted that the results are shown from 2017 onward because the results of earlier years are same as the base case. FCOL option was not taken as it was not selected in the base case. The result shows that by the year 2034 sixty-three units of GBG9, fifteen units of BRK1, and fifty one units of Wind (1020 MW) are selected with total capacity addition of $13,278 \mathrm{MW}$ in the system. The total objective function cost is about 21.72 billion dollars which is about 130 million dollars less comparing to the base case. The LOLP in year 2034 is $0.284 \%$ about 1 day per year. The reliability of the system is not as good as in the base case but meets the same reserve margins limits of minimum $5 \%$ used as a constraint. 
This also shows that to meet the same reliability criteria of LOLP more capacity additions are required and the reserve margin criteria are not as good measure when intermittent technology are considered in the system. It may also be noted that environmental costs are not considered in the analysis.

\section{Conclusions}

This paper has presented the results of a least-cost generation expansion plan using wind turbines as a candidate plant. A set of 10 wind turbines of $2 \mathrm{MW}$ capacity is considered as a single unit of $20 \mathrm{MW}$ capacity and modeled as a thermal unit in WASP with high forced outage rate according to the expected capacity factor at the selected site. The result shows that with minimum $5 \%$ reserve margin reliability criteria and the cost of unserved energy as $\$ 1.6 / \mathrm{kWh}$ the wind turbine indeed forms part of the generating system expansion economically. However, the result of reliability criteria of LOLP has shown significant difference in the two cases. Although LOLP criteria are superior to reserve margin criteria but in the presence of cost of unserved energy as balancing factor in the objective function LOLP should be automatically taken care of. On the other hand, calculating cost of unserved energy is not an easy task and needs a lot of assumptions and a reasonable sample size of survey in residential, commercial, industrial, and other sectors. As a future work it would be worthwhile to compare the high forced outage rate model of wind turbine with the negative load model. It would also be worthwhile to find the limit of maximum wind potential that can be exploited in the southern part of the country so that it can be added as a constraint to limit the number of wind turbine units selected for strategic plan.

\section{Conflicts of Interests}

The authors do not have any conflict of interests with the content of the paper.

\section{References}

[1] W. Buehring, C. Huber, and J. Marques de Souza, Expansion Planning for Electrical Generating Systems-A Guidebook, Technical Report Series No. 241, IAEA, Vienna, Austria, 1984.

[2] J. Wang and J. McDonald, Modern Power System Planning, McGraw-Hill, London, UK, 1994.

[3] J. Stoll, Least-Cost Electric Utility Planning, John Wiley \& Sons, New York, NY, USA, 1989.

[4] A. S. S. Dorvlo and D. B. Ampratwum, "Summary climatic data for solar technology development in Oman," Renewable Energy, vol. 14, no. 1-4, pp. 255-262, 1998.

[5] M. Y. Sulaiman, A. M. Akaak, M. A. Wahab, A. Zakaria, Z. A. Sulaiman, and J. Suradi, "Wind characteristics of Oman," Energy, vol. 27, no. 1, pp. 35-46, 2002.

[6] Authority for Electricity Regulation, Oman, "Study on renewable energy eesources, Oman," Final Report, 2008, http://www .aer-oman.org/images/renewables\%20study\%20may\%202008 .pdf.
[7] M. H. Albadi, E. F. El-Saadany, and H. A. Albadi, "Wind to power a new city in Oman," Energy, vol. 34, no. 10, pp. 15791586, 2009.

[8] A. Malik and A. H. Al-Badi, "Economics of wind turbine as an energy fuel saver-a case study for remote application in oman," Energy, vol. 34, no. 10, pp. 1573-1578, 2009.

[9] S. AL-Yahyai, Y. Charabi, A. Gastli, and S. Al-Alawi, "Assessment of wind energy potential locations in Oman using data from existing weather stations," Renewable and Sustainable Energy Reviews, vol. 14, no. 5, pp. 1428-1436, 2010.

[10] A. H. Al-Badi, "Wind power potential in Oman," International Journal of Sustainable Energy, vol. 30, no. 2, pp. 110-118, 2011.

[11] “OPWP's 7-year statement (2102-2018)," Oman Water and Procurement Company, 2012, http://www.omanpwp.com/PDF/ Final\%207YS\%202012-2018.pdf.

[12] Wein Automatic System Planning Package, WASP-IV, IAEA, 2003.

[13] M. Malone, “Generation planning in the 1980's," in Proceedings of the 11th National Convention of the Institute of Electrical Engineers of the Philippines, Manila, Philippines, November 1986.

[14] R. Billinton and R. Allan, Reliability Evaluation of Power System, Pitman, 1996.

[15] F. Al-Farsi, M. Al-Shihi, and Y. Al-Shokaili, "Optimal generation reserve margin for Muscat interconnected system," Final Year Project Report, SQU, Electrical Engineering Department, Muscat, Oman, 2000. 